ISSN : 2356-4164

\title{
PERLINDUNGAN ORANG SIPIL DALAM HUKUM HUMANITER INTERNASIONAL
}

\author{
Levina Yustitianingtyas
}

Fakultas Hukum Universitas Hang Tuah Surabaya

Email : firman.yusticia86@gmail.com

\begin{abstract}
ABSTRAK
Hukum Humaniter Internasional atau Internastional Humanitarian Law adalah bagian dari Hukum Internasional. Hukum Humaniter Internasional dapat diberi pengertian sebagai hukum yang mengatur tentang perlindungan korban perang. Hukum Humaniter Internasional memberikan perlindungan kepada korban perang atau mereka yang terlibat dalam pertempuran .Dalam tulisan ini akan mengkaji tentang perlindungan penduduk sipil, utamanya bagaimana hukum humaniter internasional memberikan perlindungan terhadap penduduk sipil dalam pertikaian bersenjata, termasuk orang sipil yang karena pekerjaannya harus mendapatkan perlindungan. Perlindungan terhadap orang sipil dalam pertikaian bersenjata sudah lama mendapatkan pengaturan dalam hukum internasional, baik melalui perjanjian internasional maupun melalui hukum kebiasaan internasional. Perlindungan orang sipil dalam pertikaian bersenjata berlandaskan prinsip kemanusiaan, hal ini untuk menghormati dan menjunjung tinggi harkat dan martabat manusia.
\end{abstract}

Kata kunci : hukum humaniter internasional, perlindungan korban perang, hukum internasional

\begin{abstract}
International Humanitarian Law or International Humanitarian Law is part of international law. International humanitarian law can be made to understand as the law governing the protection of war victims. International humanitarian law provides protection to victims of war or those involved in the battle.In this paper will examine on the protection of civilians, particularly how international humanitarian law provides protection of civilians in armed conflict, including civilians who because of their work must be protected. Protection of civilians in armed conflict has been a long time getting arrangements in international law, either through international treaties or through customary international law. Protection of civilians in armed conflict based on principles of humanity, it is to respect and uphold human dignity.
\end{abstract}

Keywords: international humanitarian law, the protection of victims of war, international law

\section{Pendahuluan}

Sebagaimana diketahui, bahwa Hukum Humaniter Internasional (HHI) atau International Humanitarian Law merupakan bagian dari Hukum Perang, dan hukum perang sendiri merupakan bagian dari Hukum Internasional. Hukum perang merupakan bagian hukum tertua dari hukum internasional dan sebagian besar dari 
hukum perang merupakan hukum tertulis atau telah terkodifikasi.

Secara sederhana HHI dapat diberi pengertian sebagai hukum yang mengatur tentang perlindungan korban perang (Haryomataram, 2005). Dari pengertian yang sederhana ini ada dua aktifitas bisa diperhatikan, yaitu aktifitas perang dan dan aktifitas perlindungan korban perang. Aktifitas perang dengan berbagai peraturan yang menyertainya pada kesempatan ini kita abaikan, yang perlu mendapatkan perhatian lebih lanjut adalah aktifitas perlindungan korban perang berikut ketentuan yang menyertainya. Ketentuan yang dapat dijadikan sebagai dasar dalam memberikan perlindungan korban perang pada dasarnya bersumberkan pada hukum internasional, baik yang berupa perjanjian internasional maupun hukum kebiasaan internasional.

Hukum

Internasional

Humaniter memberikan

perlindungan kepada korban perang atau mereka yang terlibat dalam pertempuran secara garis besar dapat dikategorikan menjadi; Pertama, perlindungan yang diberikan kepada Kombatan (Combatant), yaitu mereka yang terlibat aktif dalam pertempuran. Bentuk perlindungan yang diberikan kepadanya yaitu status sebagai tawanan perang bila ternyata berada di tangan pihak lawan. Sebagai tawanan perang mereka harus diperlakukan secara manusiawi dan dijamin hak-hak dan kewajibannya (Konvensi Jenewa III). Kedua, perlindungan yang diberikan kepada penduduk sipil (Civilian population), yaitu penduduk dari pihak yang bertikai yang tidak terlibat aktif dalam pertempuran. Bentuk perlindungan yang diberikan kepadanya berupa larangan untuk menjadikan mereka sebagai obyek atau sasaran serangan (Konvensi Jenewa IV). Ketiga, perlindungan yang diberikan kepada orang yang karena pekerjaanya harus dihormati dan tidak boleh dijadikan sasaran serangan.

Perlindungan terhadap penduduk sipil sebagai akibat atau karena adanya pertikaian bersenjata pada dasarnya mendapatkan pengaturan dalam hukum humaniter. Namun, dalam perkembangannya dalam memberikan perlindungan terhadap perlindungan penduduk sipil karena adanya pertikaian bersenjata di negaranya dapat dilakukan melalui cara lain, seperti pemindahan penduduk ke wilayah yang tidak digunakan sebagai arena pertikaian, namun masih dalam wilayah negara yang bertikai (internally displaced persons $=$ pengungsi internal), pemindahan penduduk ke wilayah negara lain yang aman (refugees = pengungsi internasional), atau melakukan perpindahan penduduk (Emigrants). Sebagaimana contoh situasi yang terjadi di Iraq pada sekitar Tahun 2003. Pada waktu itu penduduk Iraq, sekitar 1, 5 juta dicarikan tempat yang aman di luar kota Bagdad dari akibat pertikaian. Demikian juga sekitar 7.000 penduduk Iraq berstatus sebagai pencari suaka di Damaskus dan Amman. Sedangkan sebagian penduduk Iraq yang lain pergi meninggalkan kota atau negaranya menuju Syria dan Jordan sebagai Emigrant (Al Hassani, 2008).

Adanya bentuk-bentuk perlindungan yang demikian tentunya 
terkait dengan salah satu prinsip atau asas dalam hukum humaniter, yaitu Prinsip Pembedaan (Distinction Principle). Prinsip ini menegaskan, bahwa penduduk suatu negara yang terlibat dalam suatu pertikaian bersenjata atau berperang dibedakan atas Kombatan (Combatant) dan Penduduk Sipil (Civilian Population). Latar belakang munculnya prinsip ini, untuk mengetahui siapa yang boleh turut aktif dalam pertikaian bersenjata atau perang dan siapa yang tidak; Juga untuk menentukan siapa yang dapat dijadikan sasaran obyek serangan dan siapa yang tidak. Masing-masing kelompok tersebut di samping mempunyai hak dan kewajiban yang berbeda, serta konsekuensi yang berbeda dalam kaitannya dengan pihak musuh. Namun, dipihak lain mempunyai hak yang sama, yaitu diperlakukan secara manusiawi. Oleh karena itu dalam situasi pertikaian bersenjata atau perang seseorang harus menentukan pilihan dia akan masuk kedalam golongan mana, seseorang pada saat yang sama tidak dapat masuk kedalam dua golongan.

Berdasarkan bentuk-bentuk perlindungan yang diberikan oleh hukum humaniter tersebut di atas, pada kesempatan ini akan dikaji lebih mendalam tentang perlindungan penduduk sipil, utamanya bagaimana hukum humaniter internasional memberikan perlindungan terhadap penduduk sipil dalam pertikaian bersenjata, termasuk orang sipil yang karena pekerjaannya harus mendapatkan perlindungan?

\section{Pengaturan Internasional Terhadap Perlindungan Penduduk Sipil}

$\begin{array}{cr}\text { Perlindungan } & \text { terhadap } \\ \text { penduduk sipil dalam pertikaian }\end{array}$ bersenjata sebenarnya sudah lama menjadi perhatian negara-negara, baik yang terlibat maupun tidak dalam perang. Bahkan dalam kebiasaan berperang ditemukan asas hukum perang yang melarang penyerangan atas penduduk sipil yang tak bersenjata, sebagai orang yang berarada "di luar perang". Mereka membutuhkan perlindungan yang lebih positif, yaitu menghindarkan mereka dari serangan yang langsung. Sebelum lahirnya Konvensi jenewa 1949, perlindungan terhadap penduduk sipil memang sudah disinggung dalam Konvensi Den Haag, namun masih kurang lengkap dan hanya mengatur perlindungan penduduk sipil di wilayah yang diduduki. Sehingga dapatlah dikatakan bahwa pengaturan perlindungan penduduk sipil dalam Konvensi Jenewa IV merupakan suatu pengaturan yang baru.

Berikut akan diuraikan secara sepintas pengaturan perlindungan penduduk sipil sebelum lahirnya Konvensi Jenewa 1949, serta pengaturan perlindungan penduduk sipil dalam Konvensi Jenewa 1949 berikut Protokolnya.

\section{Instruksi Lieber Tahun 1863.}

Instruksi Lieber pada awalnya merupakan instruksi Pemerintah AS yang kemudian dianggap sebagai kodifikasi hukum perang internasional. Menurut instruksi ini, orang sipil dibedakan kedalam tiga kelompok, yaitu:

a. orang sipil yg inoffensive: mereka mendapat perlindungan pribadi, harta dan kehormatan. Mereka 
tidak boleh dibunuh, tidak boleh dijadikan budak, dipindah paksakan atau dipaksa bekerja pada pihak yang menang, dan kesucian hubungan keluarga tidak boleh dicemarkan.

b. orang sipil yg ikut serta langsung dalam permusuhan ( levee en masse) diberi kedudukan sebagai belligerent.

c. orang sipil yg terkait aktif dalam pelaksanaan tugas Angkatan Bersenjata dan bila tertangkap musuh berhak mendapatkan status tawanan perang.

\section{Konvensi Jenewa Tahun 1864.}

Konvensi ini merupakan perjanjian internasional pertama yang menetapkan perlindungan bagi korban perang, yaitu mereka yang luka di medan perang, personil dan kesatuan medik beserta peralatannya. Juga konvensi ini mengatur tingkah laku orang sipil dalam pertikaian bersenjata berikut perlindungannya

\section{Deklarasi St. Petersburg tahun 1868.}

Dalam deklarasi ini sekalipun tidak secara eksplisit mengatur orang sipil, namun secara implisit menetapkan perlindungan bagi orang sipil. Perlindungan diberikan dengan mencantumkan prinsip pembedaan dalam konsideran deklarasi tersebut. Menurut konsideran tersebut dikatakan bahwa satu-satunya sasaran sah yang dapat dijadikan sasaran serangan adalah melemahkan angkatan bersenjata musuh. Mereka yang bukan anggota angkatan bersenjata musuh tergolong orang sipil.

\section{Konvensi Den Haag Tahun 1899 dan Tahun 1907 (Konvensi Den Haag).}

Konvensi Den Haag 1907 itu sebenarnya merupakan penyempurnaan Konvensi Den Haag 1899, yang mengatur Hukum dan Kebiasaan Perang di darat. Dalam Konvensi Den Haag di atur tentang Belligerents (istilah sekarang Kombatan), yaitu mereka yang ikut aktif dalam permusuhan, oleh karenanya ia tunduk pada hukum perang. Sedangkan mereka yang tidak tergolong belligerents, yaitu orangorang yang tidak ikut dalam permusuhan adalah orang sipil. Orang sipil yang berada di wilayah penduidukan harus dilindungi dari tindakan kesewenang-wenangan pihak musuh yang mendudukinya. Secara garis besar bentuk perlindungan terhadap orang sipil itu antara lain :

- Orang sipil tidak bisa dipaksa untuk memberikan informasi tentang angkatan bersenjata pihak lawan yang bertikai, termasuk perlengkapan pertahanannya

- Mereka tidak boleh dipaksa bersumpah untuk setia kepad musuh yang menguasai

- Penghormatan hak-hak pribadi dan harta orang sipil

- Larangan penjarahan pada penduduk sipil

- Larangan pemungutan pajak dan pungutan yang sejenis secara sewenang-wenang

- Larangan penghukuman kolektif pada orang sipil

- Larangan pencabutan hak milik orang sipil secara sewenangwenang. 


\section{Konvensi Jenewa 1949}

Pada dasarnya Konvensi Jenewa IV merupakan penyempurnaan Konvensi Jenewa 1864. Konvensi Jenewa 1949 terdiri atas empat Konvensi. Sebagaimana di singgung di atas bahwa perlindungan terhadap penduduk sipil utamanya diatur dalam Konvensi IV. Konvensi IV dalam mengatur perlindungan terhadap penduduk sipil di kelompokkan atas perlindungan umum dan perlindungan khusus.

Perlindungan

umum

dimaksudkan bahwa perlindungan yang diberikan terhadap penduduk sipil tidak boleh dilakukan secara diskriminatif. Penduduk sipil adalah orang-orang yang tidak ikut aktif dalam pertempuran. Mereka dalam segala keadaan berhak atas penghormatan pribadi, hak kekeluargaan, kekayaan dan hak atas agamanya. Terhadap mereka tidak boleh dilakukan tindakan-tindakan sebagaimana disebutkan dalam Pasal 27 - 34, yaitu berupa tindakan-tindakan :

a. Melakukan pemaksaan jasmani maupun rohani untuk memperoleh keterangan;

b. Melakukan tindakan penyiksaan atau sejenisnya yang menimbulkan penderitaan jasmani;

c. Melakukan tindakan intimidasi, teror, dan penjarahan;

d. Melakukan tindakan pembalasan;

e. Larangan menghalang-halangi untuk melakukan ibadah sesuai dengan agamanya;

f. Melakukan penghukuman secara kolektif, penyanderaan, penghinaan g. Memberi kesempatan meninggalkan wilayah musuh

h. Mendapatkan jaminan makanan dan obat-obatan yang cukup;

i. Melakukan tindakan permusuhan terhadap orang sipil.

Dalam kaitanya dengan perlindungan terhadap penduduk sipil, Konvensi Jenewa mengisyaratkan pembentukan daerah keselamatan (safety zones), yaitu suatu kawasan yang terletak jauh dari medan pertempuran, untuk memberikan perlindungan kepada orang-orang sipil yang rentan terhadap akibat perang, seperti mereka yang sakit, perempuan hamil, perempuan menyusui, anak balita, orang tua. Demikian juga, perlakuan khusus harus diberikan kepada anak-anak. Mereka tidak boleh dilibatkan dalam pertempuran. Mereka harus mendapatkan bantuan dan perawatan sesuai dengan usia mereka. Lebih lagi terhadap anak yatim atau yang terpisah dengan orang tuanya harus mendapatkan perlindungan atau jaminan keselamatan. Konvensi Jenewa IV dalam kaitannya dengan perlindungan terhadap penduduk sipil, juga mengatur perlindungan terhadap orang asing yang berada di wilayah pendudukan, orang-orang yang tinggal di wilayah pendudukan, dan interniran sipil.

Ada suatu kemungkinan bahwa pada saat terjadinya sengketa bersenjata, diwilayah negara yang bertikai terdapat warganegara pihak musuh. Negara yang di wilayahnya terdapat orang yang berkewarganegaraan negara musuh tetap mempunyai kewajiban untuk 
memberikan penghormatan atau perlindungan. Bahkan mereka harus diberi ijin untuk meneinggalkan negara tersebut. Mereka dapat dipindahkan ke negara asal kapan saja, baik secara langsung maupun melalui pihak ketiga. Sedangkan terhadap orang-orang sipil yang tinggal di wilayah pendudukan harus dihormati hak-hak asasinya, seperti tidak boleh dipaksa bekerja untuk penguasa pendudukan, tidak boleh dipaksa untuk melakukan kegiatan-kegiatan militer. Penguasa pendudukan harus bertanggung jawab untuk pemeliharaan fasilitas-fasilitas umum. Penguasa pendudukan juga harus memelihara kesejahteraan anakanak, kebutuhan makanan dan kesehatan. Memperkenankan adanya bantuan yang datang dari luar negeri, manakala penguasa pendudukan tidak mampu memberikan jaminan yang demikian.

Perlindungan umum lain yang harus dilakukan oleh pihak yang bertikai terhadap orang sipil yang diinternir, yaitu sebagaimana di atur dalam Pasal 79 - 135 Konvensi Jenewa 1949. Tindakan menginternir penduduk sipil pada dasarnya melakukan tindakan administratif, jika sekiranya terdapat alasan keamanan yang riil dan mendesak. Judi bukan merupakan suatu hukuman. Dengan demikian, sekalipun penduduk sipil diintenir mereka tidak kehilangan hakhak sipilnya, mereka tetap memiliki kedudukan dan kemampuan sipil mereka.

Berdasarkan Pasal 79 Konvensi Jenewa IV, orang-orang sipil yang dapat diinternir adalah (Arlina, 1999) :

a. penduduk sipil musuh dalam wilayah pihak yang besengketa yang perlu diawasi dengan ketat demi kepentingan keamanan,

b. penduduk sipil musuh dalam wilayah pihak yang besengketa yang dengan sukarela menghendaki untuk dinternir atau karena keadaannya menyebabkan ia diinternir,

c. penduduk sipil musuh dalam wilayah yang diduduki, apabila penguasa Pendudukan menghendaki mereka perlu diinternir karena alasan mendesak;

d. penduduk sipil yang melakukan pelanggran hukum yang secara khusus bertujuan untuk merugikan Penguasa pendudukan.

Penduduk sipil di samping memperoleh perlindungan umum dari Konvensi, juga memperoleh perlindungan khusus, yaitu ditujukan pada penduduk sipil yang tergabung dalam suatu organisasi sosial atau kemanusiaan. Pada saat melaksanakan tugas-tugasnya, biasanya mereka mengenakan tanda khusus. Apabila sedang melaksanakan tugasnya, mereka harus dihormati, yaitu diberi kesempatan atau dibiarkan melaksanakan tugas-tugasnya; dan dilindungi, yaitu mereka tidak boleh dijadikan sasaran serangan militer,

\section{Protokol Tambahan 1977,} Konvensi Jenewa 1949.

Protokol Tambahan 1977

Konvensi Jenewa 1949 terdiri atas Protokol I tahun 1977 mengatur tentang Perlindungan Korban Pertikaian Bersenjata yang Bersifat Internasional; dan Protokol II Tahun 1977 Perlindungan Korban Pertikaian 
Bersenjata yang Bersifat nonInternasional. Dalam Protokol I tahun 1977 diatur tentang batasan pengertian orang sipil, yaitu setiap orang yang bukan anggota angkatan bersenjata pihak yang bertikai. Secara umum, perlindungan terhadap penduduk sipil dan orang sipil berupa larangan penyerangan terhadap mereka. Mereka menikmati perlindungan dari bahaya yang timbul dari operasi militer. Beradasrkan prinsip tersebut dapat dikatakan bahwa:

a. penduduk sipil dan orang sipil tidak boleh dijadikan obyek sasaran;

b. tindakan atau ancaman kekerasan yang dimaksudkan untuk menyebar teror dikalangan pendudu di larang;

c. Orang sipil akan menikmati perlindungan, kecuali bila ia turut serta aktif dalam permusuhan

Kemudian bila dilihat lebih rinci lagi mengenai bentuk-bentuk perlindungan yang diberikan oleh Protokol tambahan antara lain:

- $\quad$ larangan menyerang orang sipil

- $\quad$ keharusan melakukan tindakan penghati-hati dalam melakukan serangan, demi untuk melindungi orang sipil

- larangan melakukan kekerasan kepada orang sipil

- larangan melakukan pemindahan paksa orang sipil

- jaminan mendapatkan bantuan

- harus dibolehkan memberikan bantuan pada korban pertikaian bersenjata

- $\quad$ perlindungan terhadap operasi militer
- $\quad$ larangan menjadikan orang sipil sebagai sasaran pertikaian bersenjata

- larangan menjadikan kelaparan orang sipil sebagai sarana pertikaian

- larangan melakukan penyerangan bangunan dan instalasi yang mengandung kekuatan berbahaya

- memberi perlindungan orang sipil yg melakukan kemanusiaan.

Dalam memberikan perlindungan kepada penduduk sipil, hukum humaniter mengenal beberapa prinsip yaitu :

- Prinsip Kemanusiaan, prinsip ini menentukan bahwa pihak yang berperang diwajibkan untuk bertindak dengan mengutamakan aspek kemanusiaan, yaitu dilarang menggunakan kekerasan yang dapat menimbulkan penderitaan yang berlebihan. Ada beberapa ketentuan yang tidak boleh dilanggar dalam suatu konflik bersenjata, yaitu (Pictet, 1996) :

1. Seseorang yang telah jatuh di tangan musuh atau salah satu pihak yang berperang, maka hak untuk hidup harus dihormati. Prinsip ini berkaitan dengan kombatan yang tertangkap musuh. Seseorang hanya boleh dibunuh pada saat orang tersebut berada dalam suatu peperangan, dimana ia siap dalam posisi untuk dibunuh. 
Bila ia tertangkap maka harus diperlakukan dengan baik.

2. Penyiksaan, penghinaan, dan hukuman yang tidak manusiawi dilarang.

3. Seseorang diakui di hadapan hukum

4. Setiap orang dihormati untuk kehormatannya, keluarganya, pendiriannya dan kebiasaan yang ia miliki

5. Jika seorang musuh tetangkap dan menderita luka, maka tawanan tersebut berhak mendapat perawatan yang layak sampai sembuh.

6. Seseorang berhak menerima kabar dari keluarganya dan menerima kiriman yang menjadi kebutuhannya

7. Seseorang tidak boleh dicabut hak miliknya.

- Prinsip Pembedaan (Distinction Principle) adalah prinsip yang membedakan antara kombatan dan penduduk sipil dalam wilayah negara yang sedang terjadi konflik. Kombatan adalah penduduk yang aktif turut serta dalam permusuhan, sedangkan penduduk sipil adalah penduduk yang tidak turut dalam permusuhan. Prinsip ini dipandang sangat penting dalam Hukum Humaiter Internasional, karena dengan begitu dapat membedakan mana yang dapat dijadikan sasaran serang dalam permusuhan.

- Prinsip Proporsional adalah prinsip yang mempunyai tujuan untuk meyeimbangkan antara kepentiangan militer dan resiko yang akan diderita oleh penduduk sipil. Prinsip ini diatur dalam Protokol Tambahan I 1977 Sub Bagian II (F. Sugeng Istanto, 1998).

- Prinsip Larangan untuk Menyebabkan Penderitaan yang Berlebihan, pada prinsip ini erat kaitannya dengan prinsip kemanusiaan. Karena pihak yang bersengketa dilarang menimbulkan penderitaan yang berlebihan.

- Prinsip Kepentingan Militer, dalam prinsip ini ditentukan mengenai kewajiban para pihak dalam menggunakan kekuatan militer haruslah sesuai hukum. Dalam penggunaan prinsip harus melalui lima tahap yang kesemuanya haruslah dipenuhi tanpa terkecuali, yaitu:

a) Tindakan yang dilakukan tidak melanggar ketentuan Hukum Humaniter Internasional;

b) Harus benar-benar ada keharusan unrtuk melakukan tindakan tersebut;

c) Tindakan yang dilakukan dalah paling tepat untuk meraih keuntungan yang diharapkan pada saat itu;

d) Akibat dari tindakan tersebut telah memenuhi prinsip proporsionalitas;

e) Cara yang diambil sudah melalui pertimbangan segala aspek yang terkait.

Dari kelima tahap tersebut diatas, memang sangatlah penting untuk dipenuhi oleh para pihak yang mengadakan permusuhan, karena sangat dimungkinkan korban yang ditrimbulkan akibat pertikaian 
tersebut sangat banyak dan meluas. Untuk itulah aspek kemanusiaan sangat dipentingkan dan mendapat perhatian yang utama karena menyangkut hak-hak hidup yang dimiliki oleh setiap manusia.

\section{Prinsip Pembedaan (Distinction Principle)}

Prinsip pembedaan (Distinction

Principle) adalah prinsip penting dalam hukum humaniter, yaitu suatu prinsip yang membedakan atau membagi penduduk dari suatu negara yang sedang berperang atau sedang terlibat dalam konflik bersenjata ke dalam dua golongan yaitu Combatant dan Penduduk Sipil. Combatant adalah golongan penduduk yang secara aktif turut serta dalam permusuhan (hostilities), sedangkan penduduk sipil adalah golongan penduduk yang tidak turut serta dalam permusuhan. Perlunya pembedaan demikian adalah untuk mengetahui mereka yang boleh turut serta dalam permusuhan, sehingga boleh dijadikan sasaran atau obyek kekerasan, dan mereka yang tidak boleh turut serta dalam permusuhan sehingga tidak dijadikan obyek kekerasan. Ini sangat penting ditekankan karena sebenarnya perang hanya berlaku anggota angkatan bersenjata dari negara-negara yang bermusuhan. Sedangkan penduduk sipil yang tidak turut serta dalam permusuhan itu harus dilindungi dari tindakan-tindakan tersebut.

$$
\text { Menurut Jean Pictet dalam buku }
$$

Arlina Permanasari, prinsip pembedaan ini berasal dari asas umum yang dinamakan asas pembatasan, yang menyatakan 'the civilian population and invidual civilian shall enjoy general protection againts danger arising from military operation'. Dalam prinsip ini diperlukan penjabaran atau implementasi lebih lanjut ke dalam beberapa asas pelaksanaan yang selanjutnya disebut sebagai prinsip pelaksanaan (principles of application), yakni :

a) Pihak-pihak yang bersengketa setiap saat harus membedakan anatara kombatan dan penduduk sipil guna menyelamatkan penduduk sipil dan obyek-obyek sipil.

b) Penduduk sipil, demikian pula orang sipil secara perorangan, tidak boleh dijadikan obyek serangan walaupun dalam hal reprisal.

c) Tindakan maupun ancaman kekerasan yang tujuan utamanya untuk menyebarkan teror terhadap penduduk sipil adalah dilarang.

d) Pihak-pihak yang bersengketa harus mengambil segala langkah pencegahan dan memungkinkan untuk penyelamatan penduduk sipil atau setidaknya untuk menekan kerugian atau kerusakan yang tidak disengaja menjadi sekecil mungkin.

e) Hanya anggota angkatan bersenjata yang berhak menyerang dan menahan musuh.

Sebagaimana yang telah dijabarkan diatas, meskipun prinsip pembedaan ini lebih ditujukan sebagai upaya untuk melindungi penduduk sipil pada saat konflik bersenjata, tetapi secara tidak langsung prinsip ini juga melindungi para anggota angkatan 
bersenjata atau kombatan dari pihakpihak yang terlibat dalam konflik bersenjata. Karena dengan adanya prinsip pembedaan ini, akan diketahui siapa saja yang boleh turut serta dalam permusuhan dan boleh dijadikan obyek kekerasan dan siapa yang tidak boleh turut dalam permusuhan dan tidak boleh dijadikan obyek kekerasan. Dengan adanya prinsip pembedaan ini, jadi diharapkan dapat meminimalisir kemungkinan terjadinya pelanggraan yang dilakukan oleh kombatan terhadap penduduk sipil.

Dalam Hukum Humaniter Internasional, diatur pula mengenai pemberian perlindungan terhadap penduduk sipil berdasarkan klasifikasiklasifikasi ukuran tertentu pada saat terjadi koflik bersenjata yang diatur dalam Konvensi Jenewa 1949 tentang perlindungan terhadap penduduk sipil dalam konflik bersenjata, yaitu meliputi :

a. Pengaturan tentang kawasankawasan yang berada dalam wilayah sengketa., antara lain :

1. Rumah Sakit dan kawasan, serta lokasi yang aman bebas dari serangan ketika terjadi permusuhan (pasal 14 Konvensi Jenewa 1949).

2. Kawasan yang dinetralkan (pasal 15 Konvensi Jenewa 1949).

3. Kawasan

khusus berdasarkan persetujuan tertentu yang ditujukan untuk mengevakuasi korban perang (pasal 17 Konvensi Jenewa 1949).

b. Pengaturan tentang perlindungan terhadap instalasi dan personil medis, antara lain:
1. larangan penyerangan terhadap rumah sakit umum (pasal 18 Konvensi Jenewa 1949).

2. Perlindungan yang diberikan kepada petugas rumah sakit atau anggota dinas kesehatan (pasal 20 Konvensi Jenewa 1949).

3. perlindungan yang ditujukan terhadap pesawat atau angkutan kesehatan (pasal 21 dan pasal 22 Konvensi Jenewa 1949), yang meliputi pengriman bantuan kemanusiaan/obat-obatan (pasal 23 Konvensi Jenewa 1949)

c. Perlindungan bagi orang-orang yang dalam kondisi tertentu, yaitu :

1. orang-orang yang mengalami luka atau sakit dan orang-orang yang lemah serta wanita yang sedang dalam keadaan hamil pada saat terjadi permusuhan (pasal 23 Konvensi Jenewa 1949).

2. anak-anak yang terpisah dari keluarganya dan yatim piatu (pasal 24 Konvensi Jenewa 1949), maupun anggota keluarga yang kehilangan famili atau saudara kandung (pasal 26 Konvensi Jenewa 1949).

Sesuai yang tertuang dalam Konvensi Jenewa 1949, perlindungan umum yang diberikan kepada penduduk sipil tidak boleh dilakukan secara diskriminatif. Sebagaimana yang disebutkan dalam pasal 27 samapai dengan pasal 34 Konvensi IV, terhadap 
mereka (penduduk sipil) tidak boleh melakukan tindakan-tindakan sebagai berikut :

a. Melakukan pemaksaan jasmani maupun rohani untuk memperoleh keterangan;

b. Melakukan tindakan yang menimbulkan penderitaan jasmani;

c. Menjatuhkan hukuman kolektif;

d. Melakukan intimidasi, terorisme dan perampokan;

e. Melakukan pembalasan (reprisal);

f. Menjadikan merka sebagai sandera;

g. Melakukan tindakan yang menimbulkan penderitaan jasmani atau permusuhan terhadap orang-orang yang dilindungi.

\section{Penegakan Hukum Humaniter}

Penegakan hukum bertujuan untuk menjaga agar hukum itu dipatuhi. Penegakan hukum dapat dilakukan dengan paling tidak dua cara, yaitu : pertama, menumbuhkan kesadaran hukum, dan kedua, dengan cara yang bersifat ancaman atau paksaan, (Mieke Komar Kantaatmadja, 1994). Dalam penegakan hukum ada tiga unsur yang harus selalu diperhatikan, yaitu kepastian hukum, kemanfaatan, dan keadilan. Dalam penegakan hukum harus ada kompromi antara ketiga unsur tersebut. Ketiga unsur tersebut harus mendapat perhatian secara proporsional seimbang. Namun, dalam praktek tidak selalu mudah mengusahakannya (Sudikno Mertokusumo, 1991).
Demikian juga atas berlakunya hukum humaniter, yang merupakan bagian dari hukum internasional, diperlukan upaya-upaya tertentu agar pihak-pihak yang bertikai mau mengindahkan dan mematuhinya. Sehingga tujuan dari hukum humaniter tersebut akan tercapai, yaitu memberikan perlindungan kepada pihak-pihak yang menjadi korban pertikaian bersenjata. Adapun upayaupaya tersebut antara lain:

1. Menumbuhkan kesadaran.

Upaya yang demikian berkait dengan kewajiban negara yang telah meratifikasi, utamanya Konvensi Jenewa 1949 berikut Protokol Tambahan. Dalam hukum perjanjian internasional di katakan bahwa bagi negara yang telah meratifikasi suatu perjanjian internasional, mempunyai kewajiban untuk melaksanakan perjanjian tersebut sesuai dengan maksud dan tujuan perjanjian internasional di bentuk. Sedangkan bagi negara yang tidak menjadi pihak pada suatu perjanjian internasional, bila perjanjian internasional itu telah berlaku efektif dalam masyarakat internasional, dapat dikatakan bahwa prinsip-prinsip umum atau dasar dalam perjanjian tersebut telah menjadi bagian dari hukum kebiasaan internasional. Lebih-lebih atas Konvensi Jenewa 1949, yang di dalamnya mengandung prinsip-prinsip kemanusiaan atau berkaitan erat dengan masalah kemanusiaan (HAM), maka prinsip-prinip umum atau dasar dalam Konvensi Jenewa 1949 telah menjadi bagian dari hukum kebiasaan internasional, yang berarti mengikat pada semua negara yang terlibat dalam 
pertikaian bersenjata. Bila suatu negara melakukan pelanggaran atas perjanjian internasional maupun kebiasaan internasional, dapat dikatakan ia melanggar kewajiban internasional.

Dalam rangka menumbuhkan kesadaran, yang utamanya ditujukan pada negara sebagai pihak yang bertikai, namun dalam realisasinya menumbuhkan kesaradan ini termasuk di dalamnya menumbuhkan kesadaran bagi angkatan bersenjata dan atau warganegara atau penduduk suatu negara. Tentunya hal ini sejalan dengan amanah dari Konvensi Jenewa 1949, bahwa negara dalam situasi damai supaya mengadakan penyebar luasan isi Konvensi kepada penduduk negara.

\section{Melakukan Ancaman atau Paksaan} Tindakan ancaman dimaksudkan agar dengan tindakan tertentu pihak yang melakukan pelanggaran terhadap hukum humaniter kembali mentaati hukum humaniter. Bila dengan ancaman ternyata tidak berhasil mengembalikan negara untuk mentaati hukum humaniter, maka negara dapat mengambil tindakan paksa.

Tindakan ancaman atau pemaksaan yang dapat dilakukan oleh suatu negara antara lain:

a. melakukan tindakan reprisal.

\begin{tabular}{lcr}
\multicolumn{1}{c}{ Reprisal } & atau & tindakan \\
pembalasan, & yang & sebenarnya \\
merupakan & suatu tindakan yang \\
dianggap & melanggar & hukum \\
internasional & dan & dilarang, \\
sebagaimana yang diatur & antara lain \\
dalam Pasal & 46 Konvensi & I, Pasal 47 \\
Konvensi II, Pasal 13 Konvensi Jenewa
\end{tabular}

III, Pasal 33 Konvensi IV, Pasal 51 paragraf 6 Protoko II - 1977. Namun dalam batas-batas tertentu reprisal masih dibolehkan, sepenjang memperhatikan hal-hal sebagai berikut:

1) Reprisal baru boleh dilaksanakan bila sarana-sarana lain sudah tidak ada lagi,

2) Reprisal dilakukan sebagai upaya untuk mencegah pihak lawan melakukan lagi tindakan yang bertentangan dengan hukum perang,

3) Reprisal yang dilakukan tidak perlu sama dengan tindakan yang dilakukan oleh pihak lawan dan bertentangan dengan hukum,

4) Reprisal tidak boleh dilakukan secara berlebihan atau melebihi kekerasan yang dilakukan oleh lawan,

5) Reprisal harus diperintahkan oleh seorang komandan yang diberi wewenang untuk itu,

6) Reprisal againts (menentang atau melanggar), dilarang.

b. Mengadili.

Dalam konteks proses peradilan, pada dasarnya mengadili mereka yang melakukan pelanggaran terhadap hukum humaniter adalah minta pertanggung jawaban kepada pihak yang melakukan pelanggaran melalui lembaga pengadilan, dan sekaligus menunjukkan adanya pelanggaran terhadap ketentuan tertentu dari hukum humaniter. Pelanggaran terhadap hukum humaniter dapat dilakukan oleh negara atau individu. Sehingga siapapun yang 
melakukan pelanggaran terhadap hukum humaniter harus mempertanggung jawabkan perbuatannya melalui pengadilan.

Bila yang melakukan pelanggaran hukum humaniter adalah negara, maka negara yang merasa dirugikan bisa mengajukan tuntutan melalui pengadilan internasional. Walaupun dalam rangka penyelesaian sengketa antar negara, penyelesaian melalui pengadilan bukan merupakan satu-satunya cara.

$\begin{array}{ccr}\text { Bila } & \text { yang } & \text { melakukan } \\ \text { pelanggaran } & \text { terhadap } & \text { hukum }\end{array}$ humaniter adalah individu atau orang perseorangan, maka individu yang bersangkutan dapat dimintai pertanggung jawaban secara individual di depan pengadilan, baik pengadilan nasional maupun pengadilan internasional. Pengadilan internasional dapat bersifat ad-hoc maupun permanen.

\section{Penutup}

Berdasarkan uraian di atas maka dapat dikatakan bahwa:

1. Perlindungan terhadap orang sipil dalam pertikaian bersenjata sudah lama mendapatkan pengaturan dalam hukum internasional, baik melalui perjanjian internasional maupun melalui hukum kebiasaan internasional.

2. Pada masing-masing perjanjian internasional telah mengatur secara rinsci tentang perlindungan orang sipil dalam pertikaian bersenjata.

3. Perlindungan orang sipil dalam pertikaian berlandaskan

bersenjata prinsip kemanusiaan. Hal ini untuk menghormati dan menjunjung tinggi harkat dan martaban manusia.

4. Yang masih perlu mendapatkan perhatian adalah sikap negaranegara pihak dalam pertikaian bersenjata, yang masih kurang menjunjung tinggi dan menghormati orang-orang sipil sebagai pihak yang harus dilindungi.

\section{Daftar Pustaka}

Al Hassani, Zouhair, 2008, International Humanitarian Law and its Implementation in Iraq, International Review of the Red Cross, Volume 90 Number 869 March 2008.

F. Sugeng Istanto, 1998, Bahan Ajar Hukum Humaniter Internasional, Fakultas Hukum Universitas Gadjah Mada, Yogyakarta.

Haryomataram, 2005, Pengantar Hukum Humaniter, Raja Grafindo Persada, Jakarta.

J. Pictet, 1996, The Principles of International Humanitarian Law, ICRC, Geneva.

Kantaatmadja, Mieke Komar, 1994, Hukum Angkasa dan Hukum Tata Ruang, Mandar Maju, Bandung.

Konvensi I mengatur tentang Perbaikan Keadaan yang Luka dan Sakit dalam Angkatan Bersenjata di Medan Pertempuran Darat.

Konvensi II mengatur Perbaikan Keadaan Anggota Angkatan Bersenjata di Laut yang Luka, sakit dan Korban Karam. 


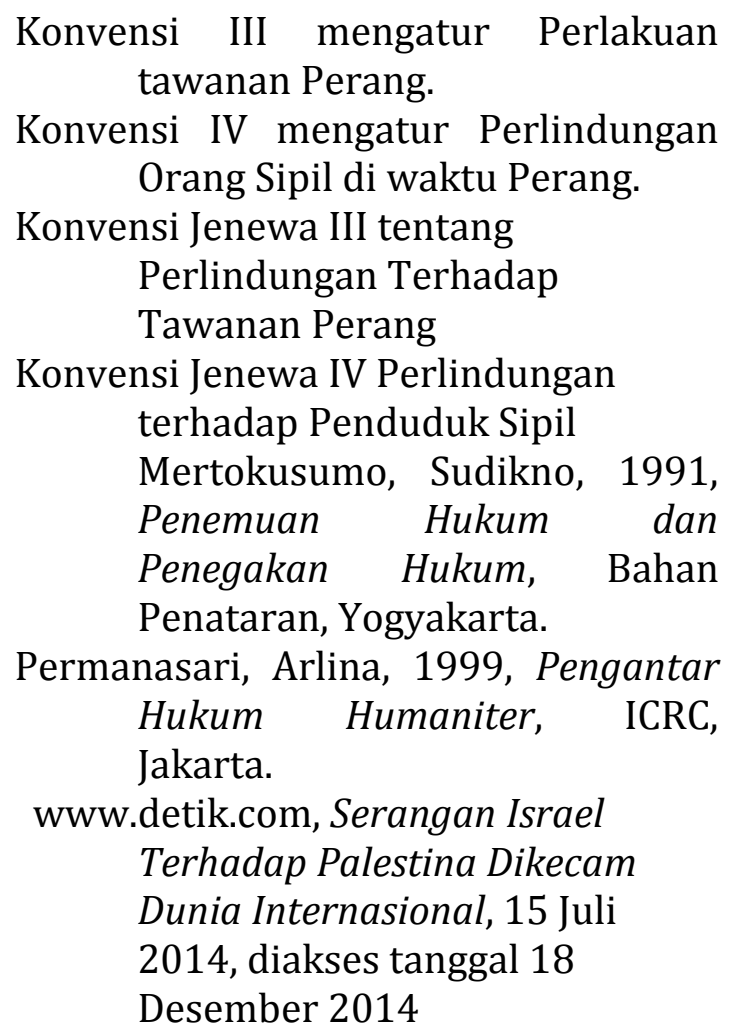

